\title{
Influence of the Period of Peach Tree Chemical Thinning on Fruit Quality
}

\author{
Caroline Farias Barreto ${ }^{1}$, Roseli de Mello Farias ${ }^{2}$, Renan Ricardo Zandoná ${ }^{1}$, \\ Carlos Roberto Martins ${ }^{2} \&$ Marcelo Barbosa Malgarim ${ }^{1}$ \\ ${ }^{1}$ Departament Crop Science, Faculty of Agronomy Eliseu Maciel, Federal University of Pelotas, Pelotas, Rio \\ Grande do Sul, Brazil \\ ${ }^{2}$ Embrapa Temperate Climate, Pelotas, Rio Grande do Sul, Brazil \\ Correspondence: Caroline Farias Barreto, Departament of Crop Science, Faculty of Agronomy Eliseu Maciel, \\ University Federal of Pelotas, Campus Capão do Leão, s/n, 96160-000, Rio Grande do Sul, Brazil. Tel: \\ 55-559-9909-0689. E-mail: carol_fariasb@hotmail.com
}

Received: May 3, 2019 Accepted: June 23, $2019 \quad$ Online Published: August 31, 2019

doi:10.5539/jas.v11n14p141 URL: https://doi.org/10.5539/jas.v11n14p141

The research is financed by Conselho Nacional de Desenvolvimento Cientifico e Tecnológico (CNPq).

\begin{abstract}
The need to decrease production costs along with the lack of man power in the countryside has asked for cultural practices which lead to these factors, such as thinning. Thus, chemical thinning has been studied as an alternative to fruit manual thinning. Therefore, this study aimed at evaluating the quality of peach tree fruits after chemical thinning with metamitron at different time periods in the south of Brazil. The experiment was carried out in a commercial peach tree orchard with cultivars 'Maciel' in Morro Redondo, Rio Grande do Sul state, Brazil, from 2015 to 2016. Treatments consisted in the application of metamitron (doses of $200 \mathrm{mg} \mathrm{L}^{-1}$ ) on the 20th, 30th, 40th, 50th and 60th day after full bloom (DAFB) and manual thinning on the 40th DAFB. Epidermis color, pulp firmness, ripeness index, soluble solids, titratable acidity, juice $\mathrm{pH}$, total phenolic compounds and antioxidant activity were evaluated. The application of metamitron in peach tree thinning did not affect peach color. Changes in the other variables related to the quality of fruits depended on the application period of metamitron in the thinning process and between crops.
\end{abstract}

Keywords: metamitron, physical-chemical, bioactive compounds

\section{Introduction}

In the main regions where peach trees are grown, thinning has been carried out manually between the 40th and the 50th day after full bloom (DAFB) (Oliveira et al., 2017). Manual thinning aims at selecting which fruits must be removed from the plant, i. e., damaged, small and badly located fruits are eliminated. Although this practice brings many benefits to peach cultures, it requires much man power, must be carried out in a short period and has high production costs (McArtney et al., 2012; Simões et al., 2013).

Peach tree cultivars exhibit high bloom, a fact that results in an excessive number of fruits which is incompatible with the production capacity of the plant (Giovanaz et al., 2016; Barreto et al., 2018). The excessive number of fruits leads to small fruits that have low commercial value (Giovanaz et al., 2016). In order to improve the quality of fruits and increase their commercial value, thinning must be carried out in the orchard (Greene \& Costa, 2013; Turk et al., 2014).

Other techniques, such as mechanical (Martin et al., 2010) and chemical thinning (Giovanaz et al., 2014; Giovanaz et al., 2016; Barreto et al., 2018) have been studied as alternatives to manual thinning of peach trees. Chemical thinning comprises the application of chemical products either during bloom or right after it, so as to cause abscission of flowers and/or fruits, thus, decreasing or eliminating the need for manual thinning. The ideal chemical thinning agent is the one that is applied after fruits are set and that causes partial abscission of fruits right after a single application (Pavanello \& Ayub, 2012). 
According to Fachinello et al. (2008), about 100 products have been studied regarding their fruit thinning properties since the 1970's. However, few have shown satisfactory thinning effects. In order to carry out chemical thinning of peach trees, some products, such as 6-benzyladenine, gibberellins, ethylene and metamitron (Meitei et al., 2013; Giovanaz et al., 2014; Giovanaz et al., 2016; Farias et al., 2017; Barreto et al., 2018), have been investigated. Metamitron may be an efficient alternative to peach tree thinning (McArtney et al., 2012). In apple tree cultures, several thinning processes have already been carried out with metamitron, which has been efficient to make fruits fall (Petri et al., 2016; Goulart et al., 2017; Gabardo et al., 2017).

Regarding peach tree cultures, there is very little information on chemical thinning with metamitron and on its effects on the quality of fruits, since the efficiency of chemical thinning depends on the cultivar, application period and product doses (Gabardo et al., 2017; Farias et al., 2017). Therefore, this study aims at evaluating the quality of peach tree fruits after chemical thinning with metamitron at different application periods in the south of Brazil.

\section{Method}

\subsection{Plant Material and Location}

The peach tree orchard consists of cultivars 'Maciel' grafted on rootstocks 'Capdeboscq'. Plants are conducted in vases; spacing between rows is $5 \mathrm{~m}$ while spacing between plants is $2 \mathrm{~m}$; density is 1,000 plants ha ${ }^{-1}$.

The experiment was carried out in a commercial orchard located in Morro Redondo, Rio Grande do Sul state, Brazil, from 2015 to 2016. Data on climate conditions throughout the experiment were provided by the meteorological station that belongs to Embrapa Clima Temperado. Considering temperatures below or equal to $7.2^{\circ} \mathrm{C}$, there were 219 cold hours in 2015 , whereas 2016 had 348 cold hours.

\subsection{Treatments}

Consisted in the application of metamitron, at doses of $200 \mathrm{mg} \mathrm{L}^{-1}$, on the 20th, 30th, 40th, 50th and 60th DAFB and manual thinning on the 40th DAFB so as to keep fruits from 10 to $15 \mathrm{~cm}$ apart. Full bloom occurred on August 6th, 2015 and on July 25th, 2016. The source of metamitron was the commercial product Goltix ${ }^{\circledR}(48 \%$ metamitron); $0.05 \%$ non-ionic spray adjuvant Silwet L- $77{ }^{\circledR}$ was added to all treatments. Jacto backpack sprayers (pressure: $40 \mathrm{psi}$ ) were used for applying different doses by aspersion. The limit of the applied volume was the runoff point, totaling, on average, $1,000 \mathrm{~L} \mathrm{ha}^{-1}$ syrup.

\subsection{Experimental Design}

The experimental design involved randomized blocks, each plot composed of five plants. The plants at the ends of each plot were disregarded, amounting to nine useful plants. Twenty fruits were used per repetition, totalizing 100 evaluated fruits by treatment.

\subsection{Variables Were Analyzed}

Fruits were picked when the background color changed from green to light yellow and evaluated for chemical and physical characteristics described as follows.

Colorimetry of the peel: was accomplished being made use of the system $\mathrm{L}^{*}, \mathrm{a}^{*}$ and $\mathrm{b}^{*}$, done by reflectometry, being used a reflectometer marks Minolta, model Chroma to put CR-300. The readings were accomplished randomly in the equatorial area of the fruit. The measured color parameters regarding to plate-pattern were: brightness $\left(L^{*}\right)$, varying from black (0) to white $(100)$; $a^{*}$, varying from green $(-60)$ to the red $(+60)$ and $b^{*}$, varying from blue $(-60)$ to yellow $(+60)$. The values of $a^{*}$ and $b^{*}$ are converted into Hue angle $\left(\mathrm{H}^{\circ}\right)$, that represents color purity according to the equations of Pinheiro 2009 (Pinheiro, 2009);

Firmness of the pulp: evaluated by a manual penetrometer (TR Turoni-Italy) brand, model 53205 with $8 \mathrm{~mm}$ tip, at two opposite points in the equatorial region of the peeled fruits, the results were expressed in N (AOAC, 2006);

Ripening index (RI): its calculation was based on absorbance difference between two wavelengths near the chlorophyll-a absorption peak. Readings were standardized, two spots on both fruit sides were verified by a portable spectrophotometer DA meter ${ }^{\circledR}$ (Turony, Italy);

Soluble solids: obtained with the Atago ${ }^{\circledR}$ brand digital refractometer, with results expressed in ${ }^{\circ}$ Brix (AOAC, 2005);

Potential of Hydrogen $(\mathrm{pH})$ : a ground sample of $10 \mathrm{~g}$ was diluted in $100 \mathrm{~mL}$ of distilled water and homogenized. The $\mathrm{pH}$ was measured by potentiometry using a digital $\mathrm{pH}$ meter (Quimus ${ }^{\circledR}$ ), duly calibrated with solutions of 4.0 and $7.0 \mathrm{pH}$, according to the Analytical Standards of the Adolfo Lutz Institute (2008). 
Titratable Acidity: we diluted $10 \mathrm{~g}$ of ground sample in $90 \mathrm{~mL}$ of distilled water and titrated with a standard 0.1 $\mathrm{N} \mathrm{NaOH}$ solution using phenolphthalein as an indicator. The result was expressed in $\mathrm{g}$ of citric acid $100 \mathrm{~g}^{-1}$ of pulp according to the Analytical Standards of the Adolfo Lutz Institute (2008).

Total phenolic compounds: were determined according to the adapted method of Singleton and Rossi 1965 using the reaction with the Folin-Ciocalteau reagent, the results were expressed in $\mathrm{mg}$ Gallic acid per $100 \mathrm{~g}$ of sample;

Antioxidant activity: was determined using the radical DPPH method adapted from Brand-Williams et al. (1995), the results were expressed in $\mathrm{mg}$ trolox per $100 \mathrm{~g}$ fresh weight.

\subsection{Statistical Analysis}

Data were subjected to the analysis of variance by the F-test while means were compared by the Tukey's test, where $\mathrm{p} \leq 0.05$.

\section{Results and Discussion}

\subsection{Colorimetry of the Peel}

The color of peach epidermis was not affected by the period in which metamitron was applied to peach tree thinning in both years under evaluation (Table 1). There was no difference between the epidermis color of fruits thinned by metamitron and the one of fruits which were manually thinned. Likewise, other studies of chemical thinning agents in peach trees did not find any changes in fruit color (Rodrigues et al., 1999). Changes in peach color are directly related to the genotype (Mayer et al., 2008), fruit ripening stage (Mathias et al., 2008), green pruning management (Gonçalves et al., 2014), amount of plant available water and the relation between fruits and sunlight (Alcobendas et al., 2013).

Table 1. Epidermis color, ripening index and pulp firmness of peach fru it pulp submitted to manual and chemical thinning with metamitron (MET), in Morro Redondo city, Rio Grande do Sul, Brazil, during 2015 and 2016

\begin{tabular}{|c|c|c|c|c|c|c|}
\hline \multirow{2}{*}{ Treatments } & \multicolumn{2}{|c|}{ Epidermis color $\left({ }^{\circ} \mathrm{Hue}\right)$} & \multicolumn{2}{|c|}{ Ripening index } & \multicolumn{2}{|c|}{ Pulp firmness (N) } \\
\hline & 2015 & 2016 & 2015 & 2016 & 2015 & 2016 \\
\hline Manual thinning & $87.44 \mathrm{~ns}$ & $87.58 \mathrm{~ns}$ & 0.95 & $0.67 \mathrm{~b}$ & $21.74 \mathrm{~b}$ & $25.11 \mathrm{ab}$ \\
\hline MET-20 DAFB & 87.22 & 86.96 & 1.03 & $0.61 \mathrm{ab}$ & $28.62 \mathrm{a}$ & $25.15 \mathrm{ab}$ \\
\hline MET-30 DAFB & 87.06 & 87.02 & 0.83 & $0.80 \mathrm{ab}$ & $22.74 \mathrm{~b}$ & $27.74 \mathrm{a}$ \\
\hline MET-40 DAFB & 87.04 & 87.58 & 0.76 & $0.72 \mathrm{ab}$ & $20.71 \mathrm{~b}$ & $25.12 \mathrm{ab}$ \\
\hline MET-50 DAFB & 88.15 & 88.67 & 0.84 & $0.97 \mathrm{a}$ & $19.88 \mathrm{~b}$ & $23.66 \mathrm{~b}$ \\
\hline MET-60 DAFB & 88.39 & 89.27 & 0.84 & $0.99 \mathrm{a}$ & $20.25 \mathrm{~b}$ & $25.92 \mathrm{ab}$ \\
\hline $\mathrm{CV}(\%)$ & 2.19 & 1.78 & 24.03 & 21.31 & 7.58 & 7.00 \\
\hline
\end{tabular}

Note. Means followed by the same lowercase letter do not differ from each other by the Tukey test at the $5 \%$ error probability level. $\mathrm{CV}(\%)=$ Coefficient of variation. $\mathrm{ns}=$ not significant.

\subsection{Ripening Index}

Ripening index of peaches was affected by the method of thinning peach trees only in the second year under evaluation (Table 1). In 2016, the ripening index of peaches was lower when plants underwent manual thinning, but it did not differ from chemical thinning with metamitron on the 20th, 30th and 40th day. These low RI values in peaches may show that there was decrease in the chlorophyll content. Therefore, the lower the ripening index, the less amount of chlorophyll (Andrade et al., 2015), due to pectin solubilization (Zhang et al., 2010; Pegoraro et al., 2015). Data collected by this study agree with the ones found by Farias et al. (2017), who observed that the ripening index of peaches yielded by cultivars 'Sensação' was lower when plants were thinned manually and with metamitron on the 20th and 30th DAFB. However, when chemical thinning with metamitron was carried out on the 50th and 60th DAFB, peaches had higher RI values (Table 1). It showed the low ripening index of these fruits in 2016.

\subsection{Firmness of the Pulp}

Peach pulp firmness was affected by the period in which metamitron was applied to peach tree thinning in both crops under evaluation (Table 1). Thus, in 2015, firmer fruits were harvested from plants thinned with metamitron on the 20th DAFB, by comparison with the other treatments. In 2016, the highest peach pulp 
firmness was found in fruits from plants subjected to thinning with metamitron on the 30th DAFB; it just differed from the one that was reached on the 50th DAFB. No direct relation could be established between periods of chemical thinning and peach pulp firmness, since physiological responses varied among crops. These results agree with Farias et al. (2017), who observed that pulp firmness was affected between periods of application of metamitron to peach tree thinning and the crop. However, pulp firmness did not exhibit any differences after the application of metamitron to apple tree thinning in four different periods (Gabardo et al., 2017). According to Souza et al. (2013), evaluating different cultivars of peaches in Minas Gerais, Brazil, found for the cultivar Sensation average firmness of $31.6 \mathrm{~N}$. In this study, regardless of the age of the pulp firmness, pulp firmness was lower than that found by Souza et al. (2013). The evaluation of the firmness of the fruits is an important characteristic to be considered, because fruits with greater firmness of the pulp have greater resistance to the transport and a longer post-harvest life.

\subsection{Soluble Solid}

Soluble solid contents varied among treatments and years under evaluation by this study (Table 2). In 2015, peaches that underwent chemical thinning with metamitron on the 30th DAFB had higher soluble solid contents than the ones that underwent manual thinning. In the second year under evaluation (2016), the highest values of soluble solids were found in peaches from plants thinned with metamitron on the 50th and 60th DAFB. Gabardo et al. (2017) also observed that soluble solid contents of apples are affected by the use of metamitron in plant thinning and by the period of application. Other studies using chemical thinners in peach trees did not find alteration of total soluble solids, pulp firmness and color index of 'Eldorado' peach fruits (Rodrigues et al., 1999). Results do not enable to establish a direct relation with periods of metamitron application because of the crop conditions. According to Raseira et al. (2014), the soluble solid of this cultivar ranges from $11^{\circ}$ Brix to $16^{\circ}$ Brix, depending on the conditions of the year. However, in the year 2015 , values lower than $11^{\circ}$ Brix were observed in almost all treatments. For this same cultivar Souza et al. (2013) found values of 11.6 soluble solids.

Table 2. Soluble solids, $\mathrm{pH}$ and titratable acidity of peach fruit pulp submitted to manual and chemical thinning with metamitron (MET) in Morro Redondo city, Rio Grande do Sul, Brazil, during 2015 and 2016

\begin{tabular}{|c|c|c|c|c|c|c|c|}
\hline \multirow{2}{*}{ Treatments } & \multicolumn{3}{|c|}{ Soluble solids ( ${ }^{\circ}$ Brix $)$} & \multicolumn{2}{|c|}{$\mathrm{pH}$} & \multicolumn{2}{|c|}{ Titratable acidity (citric acid $100 \mathrm{~g}^{-1}$ ) } \\
\hline & 2015 & & 2016 & 2015 & 2016 & 2015 & 2016 \\
\hline Manual thinning & 10.34 & $\mathrm{~b}$ & $12.70 \mathrm{bc}$ & $3.53 \mathrm{ab}$ & $3.44 \mathrm{~ns}$ & $0.74 \mathrm{ab}$ & $0.70 \mathrm{~b}$ \\
\hline MET-20 DAFB & 9.88 & $\mathrm{ab}$ & $11.74 \mathrm{c}$ & $3.60 \mathrm{a}$ & 3.44 & $0.63 \mathrm{~b}$ & $0.68 \mathrm{~b}$ \\
\hline MET-30 DAFB & 11.22 & a & $12.42 \mathrm{bc}$ & $3.48 \mathrm{~b}$ & 3.42 & $0.75 \mathrm{ab}$ & $0.71 \mathrm{~b}$ \\
\hline MET-40 DAFB & 10.26 & $\mathrm{ab}$ & $12.06 \mathrm{bc}$ & $3.48 \mathrm{~b}$ & 3.46 & $0.78 \quad \mathrm{a}$ & $0.69 \mathrm{~b}$ \\
\hline MET-50 DAFB & 10.06 & $\mathrm{ab}$ & $13.40 \mathrm{ab}$ & $3.47 \mathrm{~b}$ & 3.42 & $0.80 \mathrm{a}$ & 0.86 a \\
\hline MET-60 DAFB & 10.48 & $\mathrm{ab}$ & $13.64 \mathrm{a}$ & $3.47 \mathrm{~b}$ & 3.46 & $0.82 \mathrm{a}$ & 0.86 a \\
\hline $\mathrm{CV}(\%)$ & 6.00 & & 3.92 & 1.30 & 1.21 & 9.70 & 5.41 \\
\hline
\end{tabular}

Note. Means followed by the same lowercase letter do not differ from each other by the Tukey test at the 5\% error probability level. CV $(\%)=$ Coefficient of variation. $\mathrm{ns}=$ not significant.

\subsection{Potential of Hydrogen}

Peach pH only varied among treatments in 2015 (Table 2). In this year, peaches from manually thinned plants which underwent chemical thinning with metamitron on the 20 DAFB had the highest $\mathrm{pH}$ values. However, different doses of metamitron in peach tree thinning (Farias et al., 2017) and of ethephon in plum tree thinning (Pavanello \& Ayub, 2012) did not lead to any difference in fruit $\mathrm{pH}$. According to Alcobendas et al. (2013), $\mathrm{pH}$ of peach juice may be related to the location of the fruit in the plant.

\subsection{Titratable Acidity}

Titratable acidity of peaches exhibited differences in both crops under evaluation (Table 2). In 2105, peaches from plants thinned with metamitron on the 40th, 40th and 50th DAFB showed more acidity than the ones from trees thinned on the 20 DAFB. However, in 2016, the highest acidity contents were found in peaches from plants thinned with metamitron on the 50th and 60th DAFB, by comparison with the other treatments. The values found in this work for titratable acidity are below those reported by Santos et al. (2013). 


\subsection{Total Phenolic Compounds}

Total phenolic contents of peaches were affected by the peach tree thinning carried out in both crops under evaluation, but they had different behavior in the crops (Table 3). In the first year under evaluation, the highest total phenol content of peaches was found in plants that underwent chemical thinning with metamitron on the 30th DAFB, but it did not differ from the content found in peaches from plants that were subjected to manual thinning and thinning with metamitron on the 20th and 60th DAFB (Table 3). In the second year, peaches with the highest contents of phenolic compounds were the ones from manually thinned plants. The fact that total phenol contents were higher in fruits from manually thinned plants, by comparison with fruits from plants that underwent chemical thinning with metamitron, was also observed by Farias et al. (2017).

Table 3. Total phenols and antioxidant activity of peach fruits submitted to manual and chemical thinning with metamitron in Morro Redondo city, Rio Grande do Sul, Brazil, during 2015 and 2016

\begin{tabular}{|c|c|c|c|c|c|c|}
\hline \multirow{2}{*}{ Treatments } & \multicolumn{2}{|c|}{ Total phenols ${ }^{1}$} & \multicolumn{4}{|c|}{ Antioxidant activity $^{2}$} \\
\hline & 2015 & 2016 & 2015 & & 2016 & \\
\hline Manual thinning & $178.69 \mathrm{ab}$ & $228.38 \quad \mathrm{a}$ & 222.51 & ns & 319.74 & $\mathrm{bc}$ \\
\hline MET-20 DAFB & $181.67 \mathrm{ab}$ & $138.80 \mathrm{~d}$ & 253.44 & & 203.18 & $\mathrm{~d}$ \\
\hline MET-30 DAFB & $204.14 \quad \mathrm{a}$ & $163.01 \mathrm{c}$ & 281.06 & & 284.01 & $\mathrm{c}$ \\
\hline MET-40 DAFB & $166.10 \mathrm{~b}$ & $192.87 \mathrm{~b}$ & 288.65 & & 360.54 & $a b$ \\
\hline MET-50 DAFB & $163.95 \mathrm{~b}$ & $152.69 \mathrm{~cd}$ & 253.40 & & 264.45 & $\mathrm{c}$ \\
\hline MET-60 DAFB & $186.64 \mathrm{ab}$ & $187.14 \mathrm{~b}$ & 266.82 & & 393.68 & $\mathrm{a}$ \\
\hline $\mathrm{CV}(\%)$ & 9.06 & 6.71 & 18.75 & & 12.90 & \\
\hline
\end{tabular}

Note. ${ }^{1} \mathrm{mg}$ galic acid equivalent $100 \mathrm{~g}^{-1}$ fresh weight. ${ }^{2} \mathrm{mg}$ trolox equivalent $100 \mathrm{~g}^{-1}$ fresh weight. Means followed by the same lowercase letter do not differ from each other by the Tukey test at the $5 \%$ error probability level. CV $(\%)=$ Coefficient of variation. $n s=$ not significant.

\subsection{Antioxidant Activity}

Regarding antioxidant activity, there was no difference between fruits from manually thinned plants and plants that underwent thinning with metamitron in 2015 (Table 3). However, in 2016, the highest contents of antioxidant activity were found in fruits from plants thinned with metamitron on the 60th and 40th DAFB. Farias et al. (2017) observed that, in the case of the cultivar 'Sensação', different periods of metamitron in peach tree thinning affected the contents of antioxidant activity in fruits.

In general, quality factors of peaches under evaluation did not show any coherence among periods of metamitron application in the thinning process. Responses imply that characteristics of quality are more related to climate factors and to the crop than to the period of metamitron application. It should also be highlighted that, in practical terms, many values show realities that are very close; thus, they cannot point out any attenuate difference concerning the quality of 'Maciel' peaches.

\section{Conclusions}

In both crops, the period of application of metamitron interferes in pulp firmness, soluble solids, titratable acidity and total phenolic. The application of metamitron at different periods in chemical thinning of peach trees does not affect the epidermis color of fruits.

\section{Acknowledgements}

Conselho Nacional de Desenvolvimento Científico e Tecnológico (CNPq) for the scholarship.

\section{References}

Alcobendas, R., Mirás-Avalos, J. M., Alarcón, J. J., \& Nicolàs, E. (2013). Effects of irrigation and fruit position on size, color, firmness and sugar contents of fruits in a mid-late maturing peach cultivar. Scientia Horticulturae, 164, 340-347. https://doi.org/10.1016/j.scienta.2013.09.048

Andrade, S. B., Galarça, S. P., Gautério, G. R., Fachinello, J. C., \& Malgarim, M. B. (2015). Qualidade de pêssegos das cultivares Chimarrita e Maciel sob armazenamento refrigerado em diferentes estádios de maturação de colheita. Revista Iberoamericana de Tecnología Postcosecha, 16, 93-100. 
Association of Official Analytical Chemistry. (2005). Official methods of analysis of the Association of Official Analytical Chemistry (18th ed.). Washington, AOAC.

Barreto, C. F., Navroski, R., Zandoná, R. R., Farias, R. M., Malgarim, M. B., \& Mello-Farias, P. C. (2018). Effect of chemical thinning using 6-benzyladenine (BA) on Maciel peach (Prunus persica L.). Australian Journal of Crop Science, 12(6), 980-984. https://doi.org/10.21475/ajcs.18.12.06.PNE1086

Brand-Wiliams, W., Cuvelier, M. E., \& Berset, C. (1995). Use of a free radical method to evaluate antioxidant activity. Food Science and Technology, 28(1), 25-30. https://doi.org/10.1016/S0023-6438(95)80008-5

Fachinello, C. J., Nachtigal, J. C., \& Kersten, E. (2008). Fruticultura: Fundamentos e práticas. Pelotas: Embrapa. https://doi.org/10.1590/S0100-29452008000200001

Farias, R. de M., Barreto, C. F., Schiavon, A. V., Hellwig, C. G., Martins, C. R., Malgarim, M. B., \& Mello-Farias, P. C. (2017). Effect of chemical thinning season using metamitron on peaches 'Sensação' quality. Journal of Experimental Agriculture International, 19(6), 1-7. https://doi.org/10.9734/JEAI/ $2017 / 38522$

Gabardo, G. C., Petri, J. L., Hawerroth, F. J., Couto, M., Argenta, L. C., \& Kretzschmar, A. A. (2017). Use of Metamitron as an apple thinner. Revista Brasileira de Fruticultura, 39(3), e-514. https://doi.org/10.1590/ 0100-29452017514

Greene, D. W., \& Costa, G. (2013). Fruit Thinning in Pome- and Stone-Fruit: State of the Art. Acta Horticulturae, 998, 93-102. https://doi.org/10.17660/ActaHortic.2013.998.10

Giovanaz, M. A., Amaral, P. A., Pasa, M. S., Lima, A. P. F., Weber, D., \& Fachinello, J. C. (2016). Chemical thinning affects yield and return flowering in 'Jubileu' peach. Revista Ceres, 63(3), 329-333. https://doi.org/10.1590/0034-737X201663030008

Giovanaz, M. A., Fachinello, J. C., Goulart, C., Radünz, A. L., Amaral, P. A., \& Weber, D. (2014). Produção e qualidade de pêssegos, cv. Jubileu, com uso de fitorreguladores. Revista Ceres, 61(4), 552-557. https://doi.org/10.1590/0034-737X201461040015

Gonçalves, M. A., Picolotto, L., Azevedo, F. Q., Cocco, C., \& Antunes, L. E. C. (2014). Fruit quality and productivity of peaches submitted to different pruning dates. Ciência Rural, 44(8), 1334-1340. https://doi.org/10.1590/0103-8478cr20120617

Goulart, G., Aandrade, S. B., Bender, A., Schiavon, A. V., Aguiar, G. A., \& Malgarim, M. B. (2017). Metamitron and Different Plant Growth Regulators Combinations in the Chemical Thinning of 'Eva' Apple. Journal of Experimental Agriculture International, 18(2), 1-6. https://doi.org/10.9734/JEAI/2017/36809

Instituto Adolfo Lutz. (2008). Métodos químicos e fisicos para análise de alimentos (4th ed., p. 1020). São Paulo:Inst. Adolfo Lutz.

Mayer, N. A., Mattiuz, B., \& Pereira, F. M. (2008). Postharvest peach quality of cultivars and selections produced in Jaboticabal micro-region, São Paulo state, Brazil. Revista Brasileira de Fruticultura, 30(3), 616-621. https://doi.org/10.1590/S0100-29452008000300009

Mcartney, S. J., \& Obermiller, J. D. (2012). Comparison of the effects of metamitron on chlorophyll fluorescence and fruit set in apple and peach. Hortscience, 47(4), 509-514. https://doi.org/10.21273/ HORTSCI.47.4.509

Martin, B., Torregrosa, A., \& Garcia Brunton, J. (2010). Post-bloom thinning of peaches for canning with hand-held mechanical devices. Scientia Horticulturae, 125(4), 658-665. https://doi.org/10.1016/j.scienta. 2010.05.025

Mathias, C., Mayer, N. A., Mattiuz, B. H., \& Pereira, F. M. (2008). Effect of rootstocks and tree spacing on 'Aurora-1' peach quality. Revista Brasileira de Fruticultura, 30(1), 165-170. https://doi.org/10.1016/ j.scienta.2013.09.048

Meitei, S. B., Patel, R. K., Deka, B. C., Deshmukh, N. A., \& Singh, A. (2013). Effect of chemical thinning on yield and quality of peach cv. Flordasun. African Journal of Agricultural Research, 8(27), 3358-3565. https://doi.org/10.5897/AJAR2013.7058

Oliveira, P. D. de., Marodin, G. A. B., Almeida, G. K. de A., Gonzatto, M. P., \& Darde, D. C. (2017). Heading of shoots and hand thinning of flowers and fruits on 'BRS Kampai' peach trees. Pesquisa Agropecuária Brasileira, 52(11), 1006-1016. https://doi.org/10.1590/s0100-204×2017001100006 
Pavanello, A. P., \& Ayub, R. A. (2012). Application of ethephon thinning in chemical plum and its effect on productivity. Revista Brasileira de Fruticultura, 34, 309-316. https://doi.org/10.1590/S0100-29452012 000100040

Pegoraro, C., Tadiello, A., Girardi, C. L., Chaves, F. C, Quecini, V., Oliveira, A. C.,... Rombaldi, C. V. (2015) Transcriptional regulatory networks controlling woolliness in peach in response to preharvest gibberellin application and cold storage. BMC Plant Biology, 279, 1-14. https://doi.org/10.1186/s12870-015-0659-2

Petri, J. L., Couto, M., Gabardo, G. C., Francescatto, P., \& Hawerroth, J. F. (2016). Metamitron replacing carbaryl in post bloom thinning of apple trees. Revista Brasileira de Fruticultura, 38(4), e-903. https://doi.org/10.1590/0100-29452016903

Pinheiro, J. M. S. (2009). Tecnologia pós-colheita para a conservação de bananas da cultivar tropical (Dissertação, Universidade Estadual de Montes Claros, Brazil).

Raseira, M. D. B., Nakasu, B. H., \& Barbosa, W. (2014). Cultivares: Descrição e recomendação. In M. C. B. Raseira, J. F. M. Pereira, \& F. L. Carvalho (Eds.), C. Pessegueiro (pp. 73-141). Brasília, DF: Embrapa.

Rodrigues, A. C., Ferri, V. C., Schwartz, E., \& Fachinello, J. C. (1999). Hydrogen cyanamide on chemical thinning of peach-tree (Prunus persica, L. Batsch) flowers and fruits of Eldorado cultivar. Ciência Rural, 29(4), 625-628. https://doi.org/10.1590/S0103-84781999000400009

Souza, F. B. M. de, Alvarenga, A. A., Pio, R., Gonçalves, E. D., \& Patto, L. do S. (2013). Produção e qualidade dos frutos de cultivares e seleções de pessegueiro na Serra da Mantiqueira. Bragantia, 72(2), 133-139. https://doi.org/10.1590/S0006-87052013005000024

Simões, M. P., Vuleta, I., \& Belusic, N. (2013). Peach flowers thinning with the electro'flor equipment in 'Rich Lady' cultivar. Revista de Ciências Agrárias, 36(2), 297-302.

Singleton, V. L., Orthofer, R., \& Lamuela-Raventós, R. M. (1999). Analysis of total phenols and other oxidation substrates and antioxidants by means of folin-ciocalteu reagent. Methods in Enzymology, 299, 152-178. https://doi.org/10.1016/S0076-6879(99)99017-1

Turk, B. A., Fajt, N., Stopar, M. (2014). Tergitol as a possible thinning agent for peach cv. Redhaven. Horticultural Science, 41(2), 49-54. https://doi.org/10.17221/22/2014-HORTSCI

Zhang, L., Chen, F., Yang, H., Sun, X., Liu, H., Gong, X., Jiang, C., \& Ding, C. (2010). Changes in firmness, pectin content and nanostructure of two crisp peach cultivars after storage. Food Science and Technology, 43(1), 26-32. https://doi.org/10.1016/j.lwt.2009.06.015

\section{Copyrights}

Copyright for this article is retained by the author(s), with first publication rights granted to the journal.

This is an open-access article distributed under the terms and conditions of the Creative Commons Attribution license (http://creativecommons.org/licenses/by/4.0/). 